Marquette University

e-Publications@Marquette

Nursing Faculty Research and Publications

Nursing, College of

4-1-2015

\title{
Comparison of Nurse Staffing Based on Changes in Unit-level Workload Associated with Patient Churn
}

Ronda G. Hughes

MarquetteUniversity, ronda.hughes@marquette.edu

Kathleen Bobay

Marquette University, kathleen.bobay@marquette.edu

Nicholas A. Jolly

Marquette University, nicholas.jolly@marquette.edu

Chrysmarie Suby

Labor Management Institute, Bloomington MN

Accepted version. Journal of Nursing Management, Vol. 23, No. 3 (April 2015): 390-400. DOI.@ 2015 John Wiley \& Sons Ltd. Used with permission.

This is the peer reviewed version of the following article: "Comparison of Nurse Staffing Based on Changes in Unit-level Workload Associated with Patient Churn." Journal of Nursing Management, Vol. 23, No. 3 (April 2015): 390-400. which has been published in final form at DOI. This article may be used for non-commercial purposes in accordance With Wiley Terms and Conditions for selfarchiving. 


\title{
Comparison of Nurse Staffing Based On Changes in Unit-Level Workload Associated with Patient Churn
}

\author{
Ronda G. Hughes \\ College of Nursing, Marquette University, \\ Milwaukee, WI \\ Kathleen L. Bobay \\ College of Nursing, Marquette University, \\ Milwaukee, WI \\ Nicholas A. Jolly \\ College of Nursing, Marquette University, \\ Milwaukee, WI \\ Chrysmarie Suby \\ College of Nursing, Marquette University, \\ Milwaukee, WI
}

\begin{abstract}
Aim: This analysis compares the staffing implications of three measures of nurse staffing requirements: midnight census, turnover adjustment based on length of stay, and volume of admissions, discharges and transfers.

Background: Midnight census is commonly used to determine registered nurse staffing. Unit-level workload increases with patient churn, the movement of patients in and out of the nursing unit. Failure to account for patient churn in staffing allocation impacts nurse workload and may result in adverse patient outcomes.
\end{abstract}

Journal of Nursing Management, Vol 23, No. 3 (April 2015): pg. 390-400. DOI. This article is @ Wiley and permission has been granted for this version to appear in e-Publications@Marquette. Wiley does not grant permission for this article to be further copied/distributed or hosted elsewhere without the express permission from Wiley. 
NOT THE PUBLISHED VERSION; this is the author's final, peer-reviewed manuscript. The published version may be accessed by following the link in the citation at the bottom of the page.

Method(s): Secondary data analysis of unit-level data from 32 hospitals, where nursing units are grouped into three unit-type categories: intensive care, intermediate care, and medical surgical.

Result: Midnight census alone did not account adequately for registered nurse workload intensity associated with patient churn. On average, units were staffed with a mixture of registered nurses and other nursing staff not always to budgeted levels. Adjusting for patient churn increases nurse staffing across all units and shifts.

Conclusion: Use of the discharges and transfers adjustment to midnight census may be useful in adjusting RN staffing on a shift basis to account for patient churn.

Implications for nursing management: Nurse managers should understand the implications to nurse workload of various methods of calculating registered nurse staff requirements.

\section{Introduction}

The daily occurrence of patient churn impacts unit-level workload in hospitals (Unruh \& Fottler 2006, Duffield et al. 2009). Evidence is accumulating that higher nurse staffing is associated with better inpatient and post-discharge outcomes (Needleman et al. 2011, Weiss et al. 2011, Aiken et al. 2012, McHugh \& Ma 2013). When churn (i.e. the inflow and outflow of patient admissions, discharges and transfers) occurs, the workload of nurses increases beyond the work demands associated with patient care needs implied by the midnight census. Calculations for nurse staffing requirements for a shift and each day, based only upon the midnight census, can be enhanced to better account for changes in unit-level workload if factors relevant to 'patient churn' are considered.

Planning for the additional within-shift unit-level workload required for admitting, discharging and transferring patients, which is not accounted for by the patient census at midnight or the beginning of the shift, can be overwhelming for nurse managers. Previous research, which has primarily included data aggregated to the hospital level and has not involved unit-level analyses, provide little guidance to managers for staffing adjustments that account for fluctuations in unit-level workload occurring during a shift. This study describes and compares two methods of calculating nurse staffing requirements on a daily basis (midnight census and length of stay (LOS) adjustment to midnight census) with a measure using adjustments for patient

Journal of Nursing Management, Vol 23, No. 3 (April 2015): pg. 390-400. DOI. This article is @ Wiley and permission has been granted for this version to appear in e-Publications@Marquette. Wiley does not grant permission for this article to be further copied/distributed or hosted elsewhere without the express permission from Wiley. 
admissions, discharges and transfers (ADT) that can be applied on each shift.

\section{Overview of the literature}

Increases in care activities associated with patient admission, transfer and discharge from the unit (in other words, patient churn) have not been used as part of the calculations used to determine staffing. Midnight census has been the typical metric of workload (Baernholdt et al. 2010). While at times used interchangeably, the term patient churn intends to encompass both patient turnover and the nursing care involved in the inflow or outflow of each patient. Patient churn has been measured by adding a factor to midnight census equal to the inverse of the length of time (in days) a patient is on a unit (or in the hospital) (Unruh \& Fottler 2006) and the number of patients per bed within a unit (Duffield et al. 2009). Patient churn may place an additional burden on the workload of nurses (Duffield et al. 2009, Needleman et al. 2011), if not calculated into the workload estimation at the beginning of a shift. Failure to account appropriately for the actual unit-level workload leaves nursing staff overworked, overwhelmed, stressed and dissatisfied (Hipwell et al. 2011). The extent of failure to allocate staffing according to unit-level workload and the impact upon nurse and patient outcomes is not known.

The number of registered nurses (RNs) assigned per shift within each hospital care unit is generally determined by the number of patients (budgeted from the midnight census), the severity of patient illness, and managerial judgement of nursing workload associated with continuing patient care needs. In many instances, the severity of illness and unit-level workload are determined subjectively. Managers initially use electronic or paper-based strategies, at least 4-6 weeks in advance of publishing a staffing schedule, to determine staffing requirements based on unit budget targets, activity on hospital nursing units associated with the expected number of patients (i.e. the budgeted average daily census), total direct caregivers (e.g. RNs) for hands-on patient care, and the approved planned time off (vacation, education absence, etc.). After the schedule is published, daily and shift-by-shift staffing are adjusted to match patient census. Fluctuations in the number of patients during the hours prior to 
midnight suggest increasing, decreasing or re-allocating nursing resources (Unruh \& Fottler 2006, Kane et al. 2007, Clements et al. 2008). It is unknown if managers are consistently scheduling nurses appropriately. Research has indicated that when done correctly, the effective deployment of nursing staff improves the quality of their work and diminishes the consequences of work overload (Donaldson et al. 2005, Spence Laschinger \& Leiter 2006). Conversely, ineffective deployment, specifically when there are insufficient numbers of RNs and high or heavy nursing workload, can lead to adverse patient safety events (Weissman et al. 2007), increase in patient morbidity and mortality (Mark et al. 2004, Sales et al. 2008, Meyer et al. 2009, Needleman et al. 2011, Patrician et al. 2011, Trinkoff et al. 2011), and poor nurse outcomes including job burnout, dissatisfaction (Aiken et al. 2012, 2013), and nurses feeling that they are too busy to provide the level of care they believe necessary (Ball \& Pike 2009). Conversely, increases in nurse-to-patient ratios and reduced nursing workloads have been found to be associated with positive patient quality and outcomes of care including decreased mortality, length of stay, complications and hospital costs (Mark et al. 2004, Papastavrou et al. 2013).

Nurse managers' efforts to provide optimal staffing to meet patient care needs can be constrained by the challenge to keep costs within budget. When this results in a shift that is short-staffed, overtime can be more costly than scheduling an additional nurse for the shift (Bobay et al. 2011). Budget constraints are compounded by the ongoing threat of significant decreases in hospital revenues, when, in some instances, full-time nursing positions are decreased with negative consequences for patients, including adverse inpatient and post-discharge outcomes (Kane et al. 2007, Thungjaroenkul et al. 2007, Schwab et al. 2012). With decreased numbers of registered nurses (RNs) and increased unit-level workloads, the quality and safety of patient care are threatened (Kane et al. 2007). Nursing and hospital finance leadership are challenged to maintain or attain the right numbers for nurse staffing and skill mix [e.g. RN, licensed practical nurses (LPNs)/licensed vocational nurses (LVNs) and nursing assistants (NAs)] to optimise patient outcomes.

Three different metrics can be used to calculate nurse staffing requirements to meet unit-level workload on a daily and by shift basis:

Journal of Nursing Management, Vol 23, No. 3 (April 2015): pg. 390-400. DOI. This article is (C Wiley and permission has been granted for this version to appear in e-Publications@Marquette. Wiley does not grant permission for this article to be further copied/distributed or hosted elsewhere without the express permission from Wiley. 
midnight census, the inverse of the LOS (Unruh \& Fottler 2006), and the ADT Work Intensity Index (Wagner et al. 2005, Suby 2008). Midnight census and/or nurse-to-patient ratios have been used as representative indicators of unit-level workload (Donaldson et al. 2005), regardless of patient care needs, changes in patient status, and inflow and outflow during the 24 hours prior to midnight. Nurse staffing resources are generally negotiated during the budgeting process based on the preceding fiscal years' average midnight census; however, budgeted resources may not sufficiently represent the activity on hospital nursing units associated with daily or shift related changes nor peaks of unit-level workload. A second measure of patient churn, developed by Unruh and Fottler (2006), measures what they defined as patient turnover, a term often used interchangeably with churn. Unruh and Fottler (2006) added the inverse of the length of stay (1/LOS) to the midnight census, producing a revised estimate of workload needs that accounts for the additional work included in turnover of the same hospital bed within a 24 hour day. This adjustment method adds more nurse staffing to units with shorter LOS, which have higher levels of patient churn. The third measure, the ADT Work Intensity Index (Wagner et al. 2005, Suby 2008) was developed as an attempt to better capture the full scope of patient churn by comparing the volume of inflow and outflow of admissions, discharges and transfers to the midnight census. Unlike midnight census and length of stay adjustment, ADT adjustment can be applied at the shift level.

\section{Aim of the study}

The aims of this study were to describe and compare unit-level workload estimates of patient churn using three metrics: midnight census, the inverse of LOS added to the midnight census, and the ADT Work Intensity Index. The research questions for the study were: (1) what are nurse staffing requirements when midnight census is adjusted for patient churn using the inverse of LOS compared with unadjusted staffing based on the midnight census, (2) what are staffing requirements when patient churn is measured using the ADT Work Intensity Index, and (3) what are the differences in staffing calculations between the three measures of patient churn.

Journal of Nursing Management, Vol 23, No. 3 (April 2015): pg. 390-400. DOI. This article is (C Wiley and permission has been granted for this version to appear in e-Publications@Marquette. Wiley does not grant permission for this article to be further copied/distributed or hosted elsewhere without the express permission from Wiley. 
NOT THE PUBLISHED VERSION; this is the author's final, peer-reviewed manuscript. The published version may be accessed by following the link in the citation at the bottom of the page.

\section{Methods}

\section{Design}

A descriptive and comparative design was used to investigate the effect of adding patient churn variables (i.e. inverse of the LOS or the ADT Work Intensity Index) to staffing assignment estimates based on midnight census alone. The data were derived from a multihospital, observational cohort from the Labor Management Institute (LMI) Workforce Assessment 2-Week Survey of Hours ${ }^{\circledR}$ for calendar years 2003-2011. For this survey, self-selected units within hospitals across the USA collected unit-level data about nurse staffing and workload for each shift during a single consecutive two week period excluding holidays. The data were recorded at various times during the calendar year as determined by the hospital. A total sample of 183 units in 32 hospitals was used for this analysis. These adult acute care units were grouped into three levels of care, to account for expected differences in patient flow and staffing requirement standards. These categories included general medical and surgical, intermediate care and critical care units. Definitions for these three categories are listed in Table 1.

Table 1. Definitions of nursing units

\section{Unit category}

General medical and Medical/surgical - patients require non-intensive or intermediate surgical units

Intermediate care
units

Critical care units care for medical/surgical diagnoses

Medical and medical with telemetry units - patients require nonintensive or intermediate care for medical diagnoses as well as telemetry monitoring

Surgery and surgery with telemetry - patients require nonintensive or intermediate post surgical care as well as telemetry monitoring

Step down - post intensive care units

Telemetry - patients require telemetry monitoring post procedures and surgery

Cardiovascular intensive care units (ICUs) - cardiovascular surgical procedures requiring intensive care

Coronary care ICUs - units providing observation, care and treatment for patients with acute cardiac problems

Critical care ICUs - units where patients require medical/surgical intensive care

Journal of Nursing Management, Vol 23, No. 3 (April 2015): pg. 390-400. DOI. This article is () Wiley and permission has been granted for this version to appear in e-Publications@Marquette. Wiley does not grant permission for this article to be further copied/distributed or hosted elsewhere without the express permission from Wiley. 
Data within this database were de-identified and had been voluntarily reported to LMI for benchmarking and consultation services. Data were reviewed and verified by hospital and LMI staff against reported payroll, time and attendance, scheduling-staffing and clinical workload data for the same 2 week period. Conflicts in reported data were resolved before the data were considered completed. IRB approval was obtained from the researchers' university IRB prior to initiation of any analysis.

\section{Measures}

Daily unit-level nurse staffing workload, influenced by patient churn, was assessed with three measures. The first was the standard measure of the midnight census. The second used a measure that calculates the inverse of length of stay (1/LOS), which has been proposed to adjust for patient churn (Unruh \& Fottler 2006), multiplied by the midnight census and then added to the midnight census [( 1 /LOS $\times$ midnight census $)+$ midnight census $]$. The third staffing calculation used the ADT Work Intensity Index. This Index uses the following definitions: admissions represent new patients to the unit, transfers represent patients that are moved from one unit to another within the hospital after admission, and discharges represent patients that are moved from the unit out of the hospital. The ADT Index is calculated as the ratio between the total number of ADTs divided by the midnight census multiplied by 100 [(ADTs/midnight census $\times$ 100] (Wagner et al. 2005, Suby 2008). The ADT index is then compared to the midnight census.

The three measures were applied to calculate RN-to-patient ratio and direct care RN hours per patient day (HPPD) for each method compared with the annually determined budgeted amount by unit type. Direct care hours include the RN staff hours associated with the volume of patients or workload. To account for the variation in shift length across shifts, nursing units, and hospitals, data were standardised to 8 hour increments (i.e. 0700 to 1500 hour - shift 1 , 1500 to 2300 hour - shift 2, and 2300 to 0700 hour - shift 3) and averages across shifts were calculated for each day.

Journal of Nursing Management, Vol 23, No. 3 (April 2015): pg. 390-400. DOI. This article is (C) Wiley and permission has been granted for this version to appear in e-Publications@Marquette. Wiley does not grant permission for this article to be further copied/distributed or hosted elsewhere without the express permission from Wiley. 
NOT THE PUBLISHED VERSION; this is the author's final, peer-reviewed manuscript. The published version may be accessed by following the link in the citation at the bottom of the page.

\section{Data analysis}

The data were analysed using the Statistical Package for Social Sciences (spss) version 19.0 for Windows (SPSS Inc., Chicago, IL, USA). To assess the possible need for additional RNs based on patient churn, RN workload requirements for HPPD, total RNs, and RN-topatient ratios were calculated using the midnight census by unit type and shift, and were described and compared with unit-level requirements based on the three metrics of patient churn. As part of this analysis, repeated measures anova were used to compare unitlevel staffing as calculated using the three measures (midnight census, LOS adjustment and ADT Index adjustment) using repeated calculations by shift over the two week data collection period. Values of $P<0.05$ were considered statistically significant. Brown-Forsythe $F$ ratio was reported when the assumption of homogeneity of variance was violated across groups. Post-hoc comparisons were conducted using the Tukey HSD test for unequal sample sizes. Additionally, the Greenhouse-Geisser correction was used when the data violated the assumption of sphericity.

\section{Results}

For research question one, by definition, patient churn (using 1/LOS) was found to be higher in units with shorter LOS (see Table 2). Across all hospitals and units, units used RNs, LPNs/LVNs and NAs to staff to budgeted (or targeted) RN HPPD (i.e. the amount set forth in the annual unit budget), with $76 \%$ of shifts reporting actual RN HPPD lower than budgeted hours. In General Medical-Surgical and Intermediate Care units, the majority of shifts (72.10-95.23\%) were staffed to the budgeted RN HPPD with RN staff. Critical care units, on average, were staffed at budgeted (or targeted) RN hours with RNs an average of $86 \%$ of shifts.

Journal of Nursing Management, Vol 23, No. 3 (April 2015): pg. 390-400. DOI. This article is (C Wiley and permission has been granted for this version to appear in e-Publications@Marquette. Wiley does not grant permission for this article to be further copied/distributed or hosted elsewhere without the express permission from Wiley. 
NOT THE PUBLISHED VERSION; this is the author's final, peer-reviewed manuscript. The published version may be accessed by following the link in the citation at the bottom of the page.

Table 2. Length of stay, turnover and budgeted/actual RN HPPD

$\begin{array}{ccccc}\text { Unit type } & \begin{array}{c}\text { Average length Patient churn } \\ \text { of stay (days) } \\ \text { Mean (SD) }\end{array} & \begin{array}{c}\text { Difference in } \\ \text { Mean (SD) }\end{array} & \begin{array}{c}\% \text { of Shifts where actual } \\ \text { budgeted and actual direct care RN HPPD was } \\ \text { direct care RN HPPD } \\ \text { below budgeted direct } \\ \text { Mean (SD) }\end{array} & \begin{array}{c}\text { care RN HPPD } \\ \text { Mean Hon }\end{array}\end{array}$

1. HPPD: Hours per patient day; RN: Registered Nurse

\begin{tabular}{|c|c|c|c|c|}
\hline \multicolumn{5}{|c|}{ General medical-surgical } \\
\hline $\begin{array}{l}\text { Medical/surgical } \\
(n=43)\end{array}$ & $4.38(1.54)$ & $0.25(0.08)$ & $-4.94(5.48)$ & 83.53 \\
\hline $\begin{array}{l}\text { Medical and Medical } \\
\text { with telemetry } \\
(n=31)\end{array}$ & $4.83(2.31)$ & $0.25(0.10)$ & $-3.98(4.10)$ & 84.60 \\
\hline $\begin{array}{l}\text { Surgery and Surgery } \\
\text { with telemetry } \\
(n=22)\end{array}$ & $3.63(0.96)$ & $0.30(0.10)$ & $-2.71(2.97)$ & 72.10 \\
\hline \multicolumn{5}{|l|}{ Intermediate care units } \\
\hline Telemetry $(n=21)$ & $3.35(1.05)$ & $0.33(0.10)$ & $-6.03(4.50)$ & 95.23 \\
\hline Step down $(n=15)$ & $5.27(1.59)$ & $0.20(0.05)$ & $-2.93(4.95)$ & 79.62 \\
\hline \multicolumn{5}{|l|}{ Critical care units } \\
\hline $\begin{array}{l}\text { Cardiovascular ICU } \\
(n=7)\end{array}$ & $4.02(1.45)$ & $0.28(0.07)$ & $8.30(6.74)$ & 15.30 \\
\hline $\begin{array}{l}\text { Coronary and critical } \\
\text { care ICUs }(n=44)\end{array}$ & $4.21(1.78)$ & $0.29(0.15)$ & $5.38(7.06)$ & 13.15 \\
\hline \multicolumn{5}{|l|}{ All units } \\
\hline \multirow[t]{3}{*}{$(n=160)$} & $4.29(1.75)$ & $0.27(0.10)$ & $-1.49(7.06)$ & 76.32 \\
\hline & $F=41.44$ & $F=36.22$ & $F=325.90$ & \\
\hline & $P=0.000$ & $P=0.000$ & $P=0.000$ & \\
\hline
\end{tabular}

For research question two, patient churn, as indicated by the ADT Work Intensity Index, varied by type of nursing unit and shift (see Table 3). The highest ADT Work Intensity Index was on telemetry units $(M=60.71, \mathrm{SD}=0.13, P=0.000)$ while the lowest was on Coronary and Critical Care ICUs $(M=25.15, \mathrm{SD}=0.10, P=0.000)$. There were higher levels of patient churn across all units during the 0700-1500 hour shift (Shift 1), and particularly the 1500-2300 hour shift (Shift 2), compared with the 2300-0700 hour shift (Shift 3).

Table 3. ADT index by type of hospital unit

$\begin{array}{ccccccc}\text { Unit type } & \begin{array}{c}\text { Admissions } \\ \text { Mean (SD) }\end{array} & \text { Transfers } & \text { Discharges } & \text { Midnight } & \text { ADT index for } & \text { ADT index by } \\ \text { ceans } & \text { Mean (SD) } & \begin{array}{c}\text { census } \\ \text { Mean (SD) }\end{array} & \begin{array}{c}\text { Mean (SD) } \\ \text { shift Mean }\end{array} & \text { (SD) }\end{array}$

1. ADT: Admissions, discharges, transfers

General medical-surgical

\begin{tabular}{|c|c|c|c|c|c|c|}
\hline \multirow[t]{2}{*}{$\begin{array}{l}\text { Medical/surgical } \\
(n=43)\end{array}$} & 5.35 (3.97) & $0.53(0.88)$ & $5.02(3.89)$ & $\begin{array}{l}22.49 \\
(11.85)\end{array}$ & $48.49(0.15)$ & $\begin{array}{l}\text { Shift 1: } 22.75 \\
(1.85)\end{array}$ \\
\hline & & & & & & $\begin{array}{l}\text { Shift 2: } 22.48 \\
(2.56)\end{array}$ \\
\hline
\end{tabular}

Journal of Nursing Management, Vol 23, No. 3 (April 2015): pg. 390-400. DOI. This article is (C) Wiley and permission has been granted for this version to appear in e-Publications@Marquette. Wiley does not grant permission for this article to be further copied/distributed or hosted elsewhere without the express permission from Wiley. 
NOT THE PUBLISHED VERSION; this is the author's final, peer-reviewed manuscript. The published version may be accessed by following the link in the citation at the bottom of the page.

\begin{tabular}{|c|c|c|c|c|c|c|}
\hline Unit type & $\begin{array}{l}\text { Admissions } \\
\text { Mean (SD) }\end{array}$ & $\begin{array}{l}\text { Transfers } \\
\text { Mean (SD) }\end{array}$ & $\begin{array}{l}\text { Discharges } \\
\text { Mean (SD) }\end{array}$ & $\begin{array}{l}\text { Midnight } \\
\text { census } \\
\text { Mean (SD) }\end{array}$ & $\begin{array}{l}\text { ADT index for } \\
24 \text { hours } \\
\text { Mean (SD) }\end{array}$ & $\begin{array}{l}\text { ADT index by } \\
\text { shift Mean } \\
\text { (SD) }\end{array}$ \\
\hline & & & & & & $\begin{array}{l}\text { Shift 3: } 3.26 \\
(1.03)\end{array}$ \\
\hline \multirow{3}{*}{$\begin{array}{l}\text { Medical and Medical } \\
\text { with telemetry } \\
(n=31)\end{array}$} & $5.20(3.46)$ & $0.74(1.33)$ & $4.73(3.13)$ & $\begin{array}{l}24.10 \\
(8.93)\end{array}$ & $44.24(0.16)$ & $\begin{array}{l}\text { Shift 1: } 18.43 \\
(1.77)\end{array}$ \\
\hline & & & & & & $\begin{array}{l}\text { Shift 2: } 21.85 \\
(2.33)\end{array}$ \\
\hline & & & & & & $\begin{array}{l}\text { Shift 3: } 3.96 \\
(1.09)\end{array}$ \\
\hline \multirow{3}{*}{$\begin{array}{l}\text { Surgery and } \\
\text { Surgery with } \\
\text { telemetry }(n=22)\end{array}$} & $5.54(3.76)$ & $0.87(1.29)$ & $5.20(3.83)$ & $\begin{array}{l}21.88 \\
(9.28)\end{array}$ & $53.23(0.20)$ & $\begin{array}{l}\text { Shift 1: } 23.33 \\
(1.86)\end{array}$ \\
\hline & & & & & & $\begin{array}{l}\text { Shift 2: } 25.17 \\
(2.54)\end{array}$ \\
\hline & & & & & & $\begin{array}{l}\text { Shift 3: } 4.62 \\
(1.14)\end{array}$ \\
\hline \multirow{3}{*}{$\begin{array}{l}\text { All general medical- } \\
\text { surgical } \\
\text { units }(n=73)\end{array}$} & $5.34(3.76)$ & $0.68(1.15)$ & $4.97(3.76)$ & $\begin{array}{l}22.88 \\
(10.43)\end{array}$ & $48.02(7.07)$ & $\begin{array}{l}\text { Shift 1: } 21.37 \\
(2.48)\end{array}$ \\
\hline & & & & & & $\begin{array}{l}\text { Shift 2: } 27.31 \\
(2.51)\end{array}$ \\
\hline & & & & & & $\begin{array}{l}\text { Shift 3: } 3.99 \\
(2.11)\end{array}$ \\
\hline \multicolumn{7}{|c|}{ Intermediate care units } \\
\hline \multirow[t]{3}{*}{ Telemetry $(n=21)$} & $7.21(4.34)$ & $1.39(1.80)$ & $6.47(4.09)$ & $\begin{array}{l}24.84 \\
(9.14)\end{array}$ & $60.71(0.13)$ & $\begin{array}{l}\text { Shift 1: } 28.11 \\
(2.11)\end{array}$ \\
\hline & & & & & & $\begin{array}{l}\text { Shift 2: } 26.78 \\
(2.77)\end{array}$ \\
\hline & & & & & & $\begin{array}{l}\text { Shift 3: } 5.82 \\
(1.28)\end{array}$ \\
\hline \multirow[t]{3}{*}{ Step down $(n=15)$} & $3.80(3.13)$ & $1.25(1.44)$ & $2.47(2.54)$ & $\begin{array}{l}19.70 \\
(8.37)\end{array}$ & $38.18(0.12)$ & $\begin{array}{l}\text { Shift 1: } 14.94 \\
(1.38)\end{array}$ \\
\hline & & & & & & $\begin{array}{l}\text { Shift 2: } 18.60 \\
(2.05)\end{array}$ \\
\hline & & & & & & $\begin{array}{l}\text { Shift 3: } 4.64 \\
(1.08)\end{array}$ \\
\hline $\begin{array}{l}\text { All intermediate } \\
\text { care units }\end{array}$ & $5.79(4.23)$ & $1.33(1.66)$ & $4.80(4.04)$ & $\begin{array}{l}22.70 \\
(9.18)\end{array}$ & $52.53(7.79)$ & $\begin{array}{l}\text { Shift 1: } 25.03 \\
(2.21)\end{array}$ \\
\hline \multirow[t]{2}{*}{$(n=36)$} & & & & & & $\begin{array}{l}\text { Shift 2: } 27.31 \\
(2.51)\end{array}$ \\
\hline & & & & & & $\begin{array}{l}\text { Shift 3: } 6.75 \\
(0.93)\end{array}$ \\
\hline \multicolumn{7}{|l|}{ Critical care units } \\
\hline \multirow[t]{3}{*}{$\begin{array}{l}\text { Cardiovascular ICU } \\
(n=7)\end{array}$} & $2.60(2.13)$ & $2.30(2.10)$ & $0.44(0.80)$ & $9.74(4.14)$ & $54.76(0.10)$ & $\begin{array}{l}\text { Shift 1: } 28.38 \\
(1.50)\end{array}$ \\
\hline & & & & & & $\begin{array}{l}\text { Shift 2: } 21.88 \\
(1.20)\end{array}$ \\
\hline & & & & & & $\begin{array}{l}\text { Shift 3: } \\
4.50(0.54)\end{array}$ \\
\hline \multirow{2}{*}{$\begin{array}{l}\text { Coronary and } \\
\text { critical care ICUs } \\
(n=44)\end{array}$} & $2.52(2.43)$ & $2.13(2.17)$ & $0.44(0.79)$ & $\begin{array}{l}10.03 \\
(6.21)\end{array}$ & $25.15(0.10)$ & $\begin{array}{l}\text { Shift 1: } 20.68 \\
(1.09)\end{array}$ \\
\hline & & & & & & $\begin{array}{l}\text { Shift 2: } 23.96 \\
(1.44)\end{array}$ \\
\hline
\end{tabular}

Journal of Nursing Management, Vol 23, No. 3 (April 2015): pg. 390-400. DOI. This article is (c) Wiley and permission has been granted for this version to appear in e-Publications@Marquette. Wiley does not grant permission for this article to be further copied/distributed or hosted elsewhere without the express permission from Wiley. 
NOT THE PUBLISHED VERSION; this is the author's final, peer-reviewed manuscript. The published version may be accessed by following the link in the citation at the bottom of the page.

\begin{tabular}{|c|c|c|c|c|c|c|}
\hline Unit type & $\begin{array}{l}\text { Admissions } \\
\text { Mean (SD) }\end{array}$ & $\begin{array}{l}\text { Transfers } \\
\text { Mean (SD) }\end{array}$ & $\begin{array}{l}\text { Discharges } \\
\text { Mean (SD) }\end{array}$ & $\begin{array}{l}\text { Midnight } \\
\text { census } \\
\text { Mean (SD) }\end{array}$ & $\begin{array}{l}\text { ADT index for } \\
24 \text { hours } \\
\text { Mean (SD) }\end{array}$ & $\begin{array}{l}\text { ADT index by } \\
\text { shift Mean } \\
\text { (SD) }\end{array}$ \\
\hline & & & & & & $\begin{array}{l}\text { Shift 3: } 6.07 \\
(0.78)\end{array}$ \\
\hline \multirow[t]{3}{*}{$\begin{array}{l}\text { All critical care } \\
\text { units }(n=51)\end{array}$} & $2.53(2.39)$ & $2.15(2.16)$ & $0.44(0.79)$ & $9.99(5.97)$ & $51.25(4.37)$ & $\begin{array}{l}\text { Shift 1: } 23.33 \\
(4.40)\end{array}$ \\
\hline & & & & & & $\begin{array}{l}\text { Shift 2: } 27.31 \\
(2.51)\end{array}$ \\
\hline & & & & & & $\begin{array}{l}\text { Shift 3: } 5.39 \\
(4.21)\end{array}$ \\
\hline \multicolumn{7}{|l|}{ All units } \\
\hline \multirow[t]{3}{*}{$(n=160)$} & $4.65(3.78)$ & $1.21(1.71)$ & $3.68(3.79)$ & $\begin{array}{l}19.27 \\
(10.80)\end{array}$ & $50.15(37.58)$ & $\begin{array}{l}\text { Shift 1: } 22.39 \\
(18.52)\end{array}$ \\
\hline & & & & & & $\begin{array}{l}\text { Shift 2: } 22.86 \\
(24.42)\end{array}$ \\
\hline & & & & & & $\begin{array}{l}\text { Shift 3: } 4.90 \\
(8.75)\end{array}$ \\
\hline \multirow[t]{2}{*}{ ANOVA } & & & & & $F=1497.05$ & $F=989.75$ \\
\hline & & & & & $P=0.000$ & $P=0.000$ \\
\hline
\end{tabular}

To evaluate whether ADT increases nurse staffing requirements beyond that calculated using only the midnight census, shift-level staffing by unit type was used. The overall $F$ for differences in mean ADT Index scores was statistically significant: $F_{2,2533}=1497.05$, $P=0.000$; the corresponding effect size was a partial $\eta^{2}$ of 0.37 . In other words, after differences in nurse staffing are taken into account, about $37 \%$ of the variance in staffing over the midnight census requirement was related to ADT. The mean ADT Index scores within each of the three unit type groups were not different, with all $P$-values greater than 0.05. Post-hoc comparisons using the Tukey HSD test indicated no significant differences among the groups of units.

For research question three, adjusting for both methods of churn, the RN-to-patient ratio and the RN HPPD were consistently higher than that budgeted for and determined by the midnight census (Table 4). The RN-to-patient ratio was lower in less intensive units, including general medical/surgical $(M=5.74, \mathrm{SD}=1.62, P=0.000)$ and Intermediate Care $(M=4.48, S D=1.46, P=0.000)$, compared with critical care units $(M=1.78, \mathrm{SD}=0.49, P=0.000)$. There was less difference in patient churn (1/LOS) adjusted workload compared with unadjusted workload in units where patients had a longer length of stay (medical and medical with telemetry, as well as step down units). Comparatively, when adding the ADT Work Intensity Index to the RN-to-patient ratio, the additional workload per nurse increased

Journal of Nursing Management, Vol 23, No. 3 (April 2015): pg. 390-400. DOI. This article is @ Wiley and permission has been granted for this version to appear in e-Publications@Marquette. Wiley does not grant permission for this article to be further copied/distributed or hosted elsewhere without the express permission from Wiley. 
NOT THE PUBLISHED VERSION; this is the author's final, peer-reviewed manuscript. The published version may be accessed by following the link in the citation at the bottom of the page.

more on telemetry units (a difference of 2.51 patients), than on coronary and critical care ICUs (a difference of 1.63 patients).

Table 4. Comparison of RN workload and RN HPPD calculated by midnight census, patient churn and ADT index Unit type

Budgeted, unadjusted (based on midnight census) Adjusted 1 (patient churn (1/LOS)) Adjusted 2 (ADT)

1. HPPD: Hours per patient day; RN: Registered Nurse
RN workload (RN to Direct care RN HPPD Mean (SD)

\begin{tabular}{|c|c|c|c|}
\hline \multicolumn{4}{|l|}{ General medical-surgical } \\
\hline \multirow{3}{*}{$\begin{array}{l}\text { Medical/Surgical } \\
(n=43)\end{array}$} & Unadjusted & 1 to $5.55(2.77)$ & $5.09(2.46)$ \\
\hline & Adjusted 1 & 1 to $6.66(3.52)$ & $5.14(2.46)$ \\
\hline & Adjusted 2 & 1 to $8.06(4.54)$ & $7.41(3.51)$ \\
\hline \multirow{3}{*}{$\begin{array}{l}\text { Medical and Medical with } \\
\text { telemetry }(n=31)\end{array}$} & Unadjusted & 1 to $5.55(1.39)$ & $4.97(1.92)$ \\
\hline & Adjusted 1 & 1 to $6.82(1.70)$ & $5.02(1.92)$ \\
\hline & Adjusted 2 & 1 to $8.04(2.25)$ & $7.24(2.75)$ \\
\hline \multirow{3}{*}{$\begin{array}{l}\text { Surgery and Surgery } \\
\text { with telemetry }(n=22)\end{array}$} & Unadjusted & 1 to $4.90(1.71)$ & $4.54(1.75)$ \\
\hline & Adjusted 1 & 1 to $6.03(2.10)$ & $4.59(1.75)$ \\
\hline & Adjusted 2 & 1 to $7.52(2.98)$ & $7.02(2.78)$ \\
\hline \multicolumn{4}{|l|}{ Intermediate care units } \\
\hline \multirow[t]{3}{*}{ Telemetry $(n=21)$} & Unadjusted & 1 to $4.28(2.07)$ & $5.69(1.08)$ \\
\hline & Adjusted 1 & 1 to $5.26(2.54)$ & $5.73(1.08)$ \\
\hline & Adjusted 2 & 1 to 6.79 (3.59) & $8.89(2.18)$ \\
\hline \multirow[t]{3}{*}{ Step down $(n=15)$} & Unadjusted & 1 to $4.25(1.35)$ & $4.45(1.62)$ \\
\hline & Adjusted 1 & 1 to $5.22(1.66)$ & $4.50(1.62)$ \\
\hline & Adjusted 2 & 1 to $5.83(2.18)$ & $6.05(2.37)$ \\
\hline \multicolumn{4}{|l|}{ Critical care units } \\
\hline \multirow{3}{*}{$\begin{array}{l}\text { Cardiovascular ICU } \\
(n=7)\end{array}$} & Unadjusted & 1 to $1.20(0.94)$ & $2.04(0.92)$ \\
\hline & Adjusted 1 & 1 to $1.47(1.15)$ & $2.09(0.92)$ \\
\hline & Adjusted 2 & 1 to $1.81(1.45)$ & $3.18(1.48)$ \\
\hline \multirow{3}{*}{$\begin{array}{l}\text { Coronary and Critical } \\
\text { care ICUs }(n=44)\end{array}$} & Unadjusted & 1 to $3.26(2.05)$ & $3.79(2.02)$ \\
\hline & Adjusted 1 & 1 to $4.01(2.52)$ & $3.84(2.02)$ \\
\hline & Adjusted 2 & 1 to $4.89(3.29)$ & $5.64(3.13)$ \\
\hline \multicolumn{4}{|l|}{ All units } \\
\hline \multirow[t]{3}{*}{$(n=160)$} & Unadjusted & 1 to $4.11(2.42)$ & $4.26(2.20)$ \\
\hline & Adjusted 1 & 1 to $5.03(3.00)$ & $4.31(2.20)$ \\
\hline & Adjusted 2 & 1 to $6.10(3.83)$ & $6.29(3.28)$ \\
\hline
\end{tabular}

To evaluate possible differences in nurse staffing comparing the three measures of patient churn across the three types of shifts and unit types, repeated measures anova was performed. The three types of unit categories were tested for differences in the RN-to-patient ratio, LOS and RN HPPD. The Mauchly test for possible violation of sphericity was significant (Mauchly's $W=0.009, P=0.000$ ), and indicated significant differences between the variances of the 
differences. Because the Greenhouse-Geisser $\varepsilon$ value of 0.502 suggested that the sample variance/covariance matrix did depart substantially from sphericity, correction was made to the degrees of freedom of the $F$ ratio.

The overall $F$ for differences in the mean nurse staffing differed significantly among the three measures $\left(F_{1.02,4595.24}=4487.19\right.$, $P=0.000)$. The adjustment for patient churn using LOS slightly increased RN to patient ratios $(M=5.03, \mathrm{SD}=3.00)$ (see Table 4), compared to the midnight census $(M=4.11, \mathrm{SD}=2.42, P=0.000$, multivariate partial $\eta^{2}=0.64$ ) by at least one patient except in critical care units. Post-hoc comparisons using the Tukey HSD test indicated that the mean RN to patient ratios for the general medical-surgical and intermediate care units, which did not significantly differ from each other, were significantly different from critical care units. ADT Work Intensity Index produced a larger increase in calculated nurse staffing requirements $(M=6.29, \mathrm{SD}=3.28)$ than patient churn using LOS $(M=4.31, \mathrm{SD}=2.20)$, compared with the midnight census $\left(M=4.26, \mathrm{SD}=2.20, P=0.000\right.$, multivariate partial $\left.\eta^{2}=0.80\right)$, by an average of 2.35 RN HPPD, except in critical care units. Post-hoc comparisons using the Tukey HSD test indicated that the mean RN-topatient ratios and RN HPPD for the intermediate care and critical care units, which did not significantly differ from each other, were significantly different from the general medical-surgical units.

Due to variation in patient churn during the day that was not captured by the daily adjustments using the midnight census or inverse of the length of stay, the ADT Index was used to assess workload differences by shift. These results are reported in Table 5. Assessment of the difference between the daily numbers of patients by shift and the total number of patients at midnight, found the largest differences in the number of patients associated with ADT on Shift 1 $(M=4.47, \mathrm{SD}=4.02)$ and Shift $2(M=4.22, \mathrm{SD}=3.83)$ were significant: $F_{2,5152}=989.75, P=0.000$, multivariate partial $\eta^{2}=0.278$. The within-day census was higher than the midnight census for each of the three shifts.

Journal of Nursing Management, Vol 23, No. 3 (April 2015): pg. 390-400. DOI. This article is (C) Wiley and permission has been granted for this version to appear in e-Publications@Marquette. Wiley does not grant permission for this article to be further copied/distributed or hosted elsewhere without the express permission from Wiley. 
NOT THE PUBLISHED VERSION; this is the author's final, peer-reviewed manuscript. The published version may be accessed by following the link in the citation at the bottom of the page.

Table 5. Differences in RN workload, shift-by-shift, between patient assignment, turnover and ADT

\begin{tabular}{|c|c|c|c|c|c|c|c|c|c|}
\hline \multirow[b]{2}{*}{ Unit type } & \multicolumn{3}{|c|}{ Shift 1 (0700-1500 hour) } & \multicolumn{3}{|c|}{ Shift 2 (1500-2300 hour) } & \multicolumn{3}{|c|}{ Shift 3 (2300-0700 hour) } \\
\hline & $\begin{array}{c}\text { Staffing, } \\
\text { based } \\
\text { on } \\
\text { midnight } \\
\text { census } \\
\text { (HPPD) } \\
\text { Mean } \\
\text { (SD) }\end{array}$ & $\begin{array}{l}\text { ADT } \\
\text { index } \\
\text { (8 hours } \\
\text { ) Mean } \\
\text { (SD) }\end{array}$ & $\begin{array}{c}\text { Differenc } \\
\text { e in RN } \\
\text { staffing } \\
\text { needed } \\
\text { (HPPD) } \\
\text { Mean } \\
\text { (SD) }\end{array}$ & $\begin{array}{c}\text { Staffing } \\
\text {, based } \\
\text { on } \\
\text { midnig } \\
\text { ht } \\
\text { census } \\
\text { (HPPD) } \\
\text { Mean }\end{array}$ & $\begin{array}{l}\text { ADT } \\
\text { index } \\
\text { (8 hour } \\
\text { s) Mean } \\
\text { (SD) }\end{array}$ & $\begin{array}{c}\text { Differenc } \\
\text { e in RN } \\
\text { staffing } \\
\text { needed } \\
\text { (HPPD) } \\
\text { Mean } \\
\text { (SD) }\end{array}$ & $\begin{array}{c}\text { Staffing, } \\
\text { based } \\
\text { on } \\
\text { midnight } \\
\text { census } \\
\text { (HPPD) } \\
\text { Mean } \\
\text { (SD) }\end{array}$ & $\begin{array}{l}\text { ADT } \\
\text { index } \\
\text { (8 hour } \\
\text { s) Mean } \\
\text { (SD) }\end{array}$ & $\begin{array}{c}\text { Differenc } \\
\text { e in RN } \\
\text { staffing } \\
\text { needed } \\
\text { (HPPD) } \\
\text { Mean } \\
\text { (SD) }\end{array}$ \\
\hline
\end{tabular}

1. ADT: Admissions, discharges, transfers

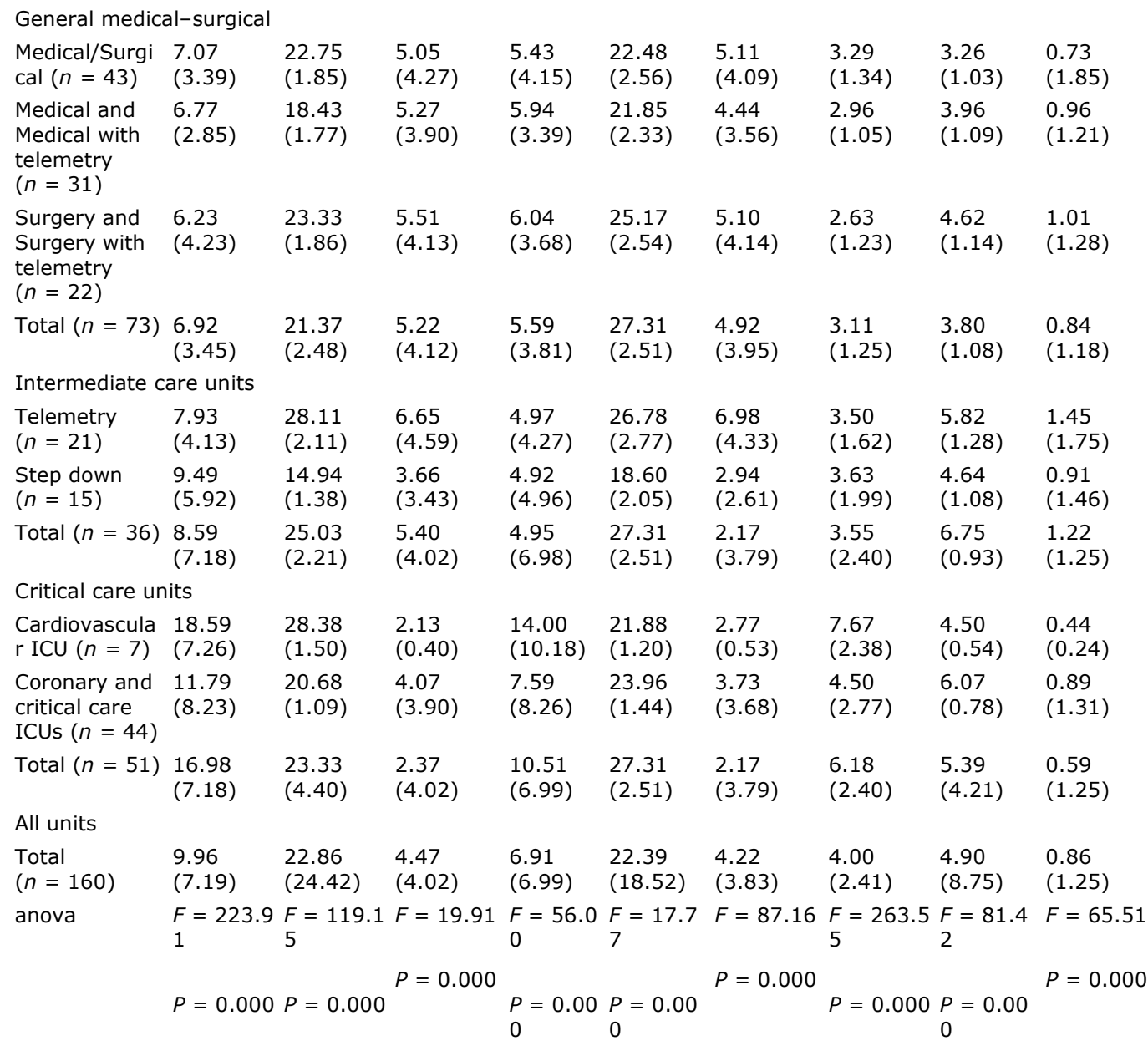

When the ADT Work Intensity Index was used in determining RN staffing across all hospitals throughout all three shifts, each type of hospital unit would have needed additional RN staffing. This increased need ranged from a mean of $0.91(S D=1.46)$ to $6.98(S D=4.33)$ additional RNs when patient churn was the highest because of ADT. been granted for this version to appear in e-Publications@Marquette. Wiley does not grant permission for this article to be further copied/distributed or hosted elsewhere without the express permission from Wiley. 
NOT THE PUBLISHED VERSION; this is the author's final, peer-reviewed manuscript. The published version may be accessed by following the link in the citation at the bottom of the page.

These numbers relate to the difference in budgeted and actual direct care RN HPPD in Table 2.

\section{Discussion}

A method of understanding unit-level workload based on admissions, transfers and discharges, differentiated by type of nursing unit, was presented in this study. Both the inverse of the length of stay and ADT Work Intensity Index adjustments to staffing calculations increase the number of nursing especially RN staff needed as estimated by the midnight census. Unlike other methods, ADT as a single measure can be used in shift-level staffing calculations.

Findings from this analysis are similar to previous research that assessed patient churn (using 1/LOS) and workload (using ADT) at the unit level within hospitals (Wagner et al. 2005, Duffield et al. 2009, Baernholdt et al. 2010), although each used only one measure of unitlevel workload with nurse staffing calculations. Two earlier studies assessed unit-level workload on only one type of nursing unit (Kiekkas et al. 2008, Meyer et al. 2009). Two other earlier studies used large administrative datasets that aggregated data at the hospital level, which did not enable an understanding of the differences among types of units within a hospital (Unruh \& Fottler 2006, Weissman et al. 2007).

Comparison of the measures of unit-level workload with patient churn indicated that the ADT Work Intensity Index offers a method for adjusting nurse staffing when ADTs are present during a shift. Doing so accounts for the complexity of patient churn, thereby potentially better meeting patient care needs and utilising resources effectively. With many units in this analysis consistently staffed below budget for RNs, using the inverse of the length of stay adjustment may assist managers in budgeting and projecting nurse staffing needs to meet patient care demands, but it does not fully reflect patient churn as it occurs shift-by-shift.

The overall average LOS in this study was lower than that reported by Unruh and Fottler (2006), in part due to a downward national trend in LOS. Overall, the average length of stay (ALOS) was similar to that reported by Duffield et al. (2009), but neither (i.e. 
Duffield et al. 2009 nor Unruh \& Fottler 2006) reported ALOS by type of unit. The rate of patient churn using the ADT Work Intensity Index method was higher than that reported by Unruh and Fottler (2006), most likely as a result of patient transfers included in this analysis. This may also have occurred by using direct care RNs compared with RN full-time equivalents used by Unruh and Fottler (2006). Differences in the rates of patient churn may also be due to a variety of reasons including not being able to assess changes in patient morbidity or the appropriateness of placement of patients to a particular unit at the time admission (e.g. patient admission to medical-surgical unit instead of telemetry unit due to a lack of available beds in telemetry).

Workload increases with changes and disruptions in the workflow associated with patient admissions, discharges and transfers, just as it does with changes in patient acuity and needs (Dunton \& Schumann 2005, Unruh 2008). Without increasing the number of RNs during peak times of ADT, higher rates of 'missed care' may be observed (Kalisch \& Lee 2012). Both patient churn calculations (the $1 /$ LOS and ADT Work Intensity Index) prompt adding staff at peak times. Similar to previous findings (Duffield et al. 2009), we found that high ADT work intensity is often associated with shortened average lengths of stay (e.g. ICU) and low ADT work intensity is often associated with longer lengths of stay. Staffing for patient churn has different implications among the types of units, given bed capacity and regulated $\mathrm{RN}$-to-patient ratios.

Units that were not critical care units in this study sample were understaffed with RNs based on patient volume at midnight. While nurse managers may be under pressure to not exceed their unit staffing budget, the increased workload demands associated with patient churn throughout shift 1 or shift 2 may not be adequately met with sufficient numbers of RNs, if staffing is only based on midnight census. There may be challenges in terms of adhering to set or prescribed RN-to-patient ratios if they do not reflect changes in unit workload due to ADT. The amount of time registered nurses spend with patients varies and can be significantly increased or decreased during a shift by the churn of patients.

Unit census by shift and midnight census in this analysis were similar to one previous study, where the mean total scores of the daily

Journal of Nursing Management, Vol 23, No. 3 (April 2015): pg. 390-400. DOI. This article is ( Wiley and permission has been granted for this version to appear in e-Publications@Marquette. Wiley does not grant permission for this article to be further copied/distributed or hosted elsewhere without the express permission from Wiley. 
census varied at different times during a 24 hour period in two units of one hospital (Beswick et al. 2010). In this analysis, occupancy during the first and second shifts was higher than the occupancy based on the midnight census. Since there is patient churn throughout the day, and peaks in RN workload during these times that exceeded the RN-topatient ratios at the beginning of the shift, the midnight census should not be used as the sole measure for the allocation of nursing resources. However, while both LOS and ADT-based adjustments add to midnight census calculations, they are relevant only when the shift census is at or exceeds the midnight census. When the shift census falls below the midnight census, staffing can be effectively managed through reassignment, or reduction.

Another important consideration is the nursing skill mix among the units. In this analysis, it was more common to find a higher percentage of RNs per shift in higher acuity and ADT work intensity units. While there were fewer shifts in the critical care units with a lower number of RNs than budgeted direct care RN HPPD, it appears that direct care RN HPPD may not be staffed with RNs, but a mixture of nursing staff (e.g. LPN/LVN, NA and RN). Since the percent of RN hours is the basis for the RN-to-patient ratios and unit budgets, and higher levels of RN skills are needed in intermediate and critical care units, consideration should be given to the minimal number of RNs needed per shift, not just nursing staff.

Several areas require further research. It is important to assess whether the impact of benchmarking ADT work intensity by unit to nationally representative standards could enable more effective unitlevel budgeting and staffing by shift. Further analysis is also needed to quantify the amount of time it takes for major nursing responsibilities, including the time to admit or transfer/discharge a patient, as well as the amount of time for responding to patient safety events (e.g. a patient fall), among other nursing activities. The average time for nurses to complete admission assessments, discharge preparation and transfers has not been well documented. This information would be useful in quantifying some of what nurses do, potentially providing decision makers with critical information to determine strategies for improvement in care delivery processes, including the effective allocation of resources and the determination of work task assignments of staff to ensure efficiencies in the work of nurses. 


\section{Implications for nursing management}

Significant changes in health care reimbursement, financial penalties associated with poor performance and other financial constraints will continue to cut into nursing budgets. All managers are pressured to meet the demands of budgeting within the narrow operating budgets at the front line of care. When units are understaffed, overtime hours can increase and nurse sensitive patient outcomes may be negatively affected. Unit staffing needs to reflect patient care needs and changes in nurse workload associated with patient churn that occur during shifts. The midnight census inadequately represents nurse workload. The findings reported here provide managers with a methodology for churn-based adjustments, rationale and estimates for negotiating budget targets for nurse staffing. Once we understand the impact of workload increases associated with admissions, transfers and discharges, matching nurse staffing to nurse workload on each unit within hospitals will be more efficient and effective.

\section{Limitations of the study}

This study has several limitations. First, it was not possible to assess for associations between unit-level workload, patient acuity, time to complete particular tasks (such as a patient admission, transfer or discharge), or nurse competencies with the data available for this study. Second, measuring unit-level or RN-level workload does not account for organisational factors (e.g. number of nurses employed within a hospital to provide patient care), patient acuity or RN characteristics. Lastly, it was not possible to assess the impact of critical changes in a patient's health status and patients off the unit for procedures or testing on unit-level workload.

\section{Conclusions}

Determining nurse staffing based on historic trends of midnight census does not account for peak increases in unit-level workload that occur during the busy times of the day when patients are being admitted to, transferred, or discharged from the unit, primarily during the day and evening shifts. The use of the ADT-Indexed staffing 
calculation may be a more accurate indicator of needed RN staffing when determining scheduling and staffing requirements for each unit and shift. Staffing at appropriate levels to match the work intensity created by patient churn will avoid adverse and costly patient outcomes associated with understaffing.

\section{Acknowledgements}

We wish to acknowledge the invaluable contributions by Dr Marianne Weiss, Marquette University.

\section{Source of funding}

There were no funds from any grants or contracts that supported the work of this analysis. This research was supported through institutional salaries.

\section{Ethical approval}

Marquette University, May 2012, exempt approval.

\section{Ancillary}

\section{References}

Aiken L.H., Sermeus W., Van den Heede K. et al. (2012) Patient safety, satisfaction, and quality of hospital care: cross sectional surveys of nurses and patients in 12 countries in Europe and the United States. British Medical Journal 344, e1717.

Aiken L.H., Sloane D.M., Bruyneel L. et al. (2013) Nurses' reports of working conditions and hospital quality of care in 12 countries in Europe. International Journal of Nursing Studies 50 (2), 143-153.

Baernholdt M., Cox K. \& Scully K. (2010) Using clinical data to capture nurse workload: implications for staffing and safety. CIN: Computers, Informatics Nursing 28 (4), 229-234.

Ball J. \& Pike G. (2009) Past Imperfect, Future Tense: Nurses' Employment and Morale in 2009. Royal College of Nursing, London.

Beswick S., Hill P.D. \& Anderson M.A. (2010) Comparison of nurse workload approaches. Journal of Nursing Management 18, 592-598.

Bobay K.L., Yakusheva O. \& Weiss M.E. (2011). Outcomes and cost analysis of the impact of unit-level nurse staffing on post-discharge utilization. Nursing Economics 29 (2), 69-78, 87.

Journal of Nursing Management, Vol 23, No. 3 (April 2015): pg. 390-400. DOI. This article is @ Wiley and permission has been granted for this version to appear in e-Publications@Marquette. Wiley does not grant permission for this article to be further copied/distributed or hosted elsewhere without the express permission from Wiley. 
NOT THE PUBLISHED VERSION; this is the author's final, peer-reviewed manuscript. The published version may be accessed by following the link in the citation at the bottom of the page.

Clements A., Halton K., Graves N. et al. (2008) Overcrowding and understaffing in modern health-care systems: key determinants in meticillin-resistant Staphylococcus aureus transmission. The Lancet Infectious Disease 8, 427-434.

Donaldson N., Bolton L.B., Aydin C. et al. (2005) Impact of California's licenses nurse-patient ratios on unit-level nurse staffing and patient outcomes. Policy Politics and Nursing Practice 6 (3), 198-210.

Duffield C., Diers D., Aisbett C. et al. (2009) Churn: patient turnover and case mix. Nursing Economics 27 (3), 185-191.

Dunton N. \& Schumann M.J. (2005) Early evidence on California staffing ratios should be interpreted with caution. Policy, Politics, and Nursing Practice 6, 354-357.

Hipwell A.E., Tyler P.A. \& Wilson C.M. (2011) Sources of stress and dissatisfaction among nurse in four hospital environments. British Journal of Medical Psychology 62 (1), 71-79.

Kalisch B. \& Lee K. (2012) Missed nursing care: magnet versus non-Magnet hospitals. Nursing Outlook 60, 32-39.

Kane R.L., Shamliyan T., Mueller C. et al. (2007) Nurse Staffing and Quality of Patient Care. Evidence Report/Technology Assessment No. 151 (Prepared by the Minnesota Evidence-based Practice Center under Contract No. 290-02-0009.) AHRQ Publication No. 07-E005. Agency for Healthcare Research and Quality, Rockville, MD.

Kiekkas P., Sakellaropoulos G., Brokalaki H. et al. (2008) Association between nursing workload and mortality of intensive care unit patients. Journal of Nursing Scholarship 40 (4), 385-390.

Mark B.A., Harless D.W., McCue M. et al. (2004) A longitudinal examination of hospital registered nurse staffing and quality of care. Health Services Research 39, 279-300.

McHugh M.D. \& Ma C. (2013) Hospital nursing and 30-day readmissions among Medicare patients with heart failure, acute myocardial infarction, and pneumonia. Medical Care 51 (1), 52-59.

Meyer R.M., Wang S., Li X. et al. (2009) Evaluation of a patient care delivery model: patient outcomes in acute cardiac care. Journal of Nursing Scholarship 41 (4), 399-410.

Needleman J., Buerhaus P., Pankratz S. et al. (2011) Nurse staffing and inpatient hospital mortality. New England Journal of Medicine 364, 1037-1045.

Papastavrou E., Andreau P. \& Efstathiou G. (2013) Rationing of nursing care and nurse-patient outcomes: a systematic review of quantitative studies. International Journal of Health Planning and Management. doi: $10.1002 / \mathrm{hpm} .2160$

Journal of Nursing Management, Vol 23, No. 3 (April 2015): pg. 390-400. DOI. This article is @ Wiley and permission has been granted for this version to appear in e-Publications@Marquette. Wiley does not grant permission for this article to be further copied/distributed or hosted elsewhere without the express permission from Wiley. 
NOT THE PUBLISHED VERSION; this is the author's final, peer-reviewed manuscript. The published version may be accessed by following the link in the citation at the bottom of the page.

Patrician P.A., Loan L., McCarthy M. et al. (2011) The association of shift-level nurse staffing with adverse patient events. Journal of Nursing Administration 41 (2), 64-70.

Sales A., Sharp N., Li Y.F. et al. (2008) The association between nursing factors and patient mortality in the Veterans Health Administration: the view from the nursing unit level. Medical Care 46, 938-945.

Schwab F., Meyer E., Geffers C. et al. (2012) Understaffing, overcrowding, inappropriate nurse: ventilated patient ratio and nosocomial infections: which parameter is the best reflection of deficits? Journal of Hospital Infection 80 (2), 133-139.

Spence Laschinger H. \& Leiter M. (2006) The impact of nursing work environments on patient safety outcomes: the mediating role of burnout engagement. Journal of Nursing Administration 36 (5), 259267.

Suby C. (2008) Impact of admissions, discharges, transfers (ADT) on average length of stay (ALOS) decreasing length of stay impacts admissions, ALOS, OT\% compared to med errors and patient falls. Perspectives on Staffing and Scheduling 29 (1), 1-3.

Thungjaroenkul P., Cummings G.C. \& Embleton A. (2007) The impact of nurse staffing on hospital costs and patient length of stay: a systematic review. Nursing Economics 25 (5), 255-265.

Trinkoff A.M., Johantgen M., Storr C.L. et al. (2011) Nurses' work schedule characteristics, nurse staffing, and patient mortality. Nursing Research $60(1), 1-8$.

Unruh L. (2008) Nurse staffing and patient, nurse, and financial outcomes. American Journal of Nursing 108 (1), 62-71.

Unruh L.Y. \& Fottler M.D. (2006) Patient turnover and nursing staff adequacy. Health Services Research 41, 599-612.

Wagner C.W., Budreau G. \& Everett L.Q. (2005) Analyzing fluctuating unit census for timely staffing intervention. Nursing Economics 23 (2), 8590.

Weiss M., Yakusheva O. \& Bobay K. (2011) Nursing staffing, readiness for hospital discharge, and post-discharge utilization. Health Services Research 46 (5), 1473-1494.

Weissman J.S., Rothschild J.M., Bendavid E. et al. (2007) Hospital workload and adverse events. Medical Care 45, 448-455.

Journal of Nursing Management, Vol 23, No. 3 (April 2015): pg. 390-400. DOI. This article is (C) Wiley and permission has been granted for this version to appear in e-Publications@Marquette. Wiley does not grant permission for this article to be further copied/distributed or hosted elsewhere without the express permission from Wiley. 